\title{
PENGARUH BUDAYA ORGANISASI KOMITMEN ORGANISASIONAL DAN KOMPENSASI TERHADAP RETENSI KARYAWAN
}

\author{
I Putu Agus Praditya Adi Putra ${ }^{1}$ \\ I Wayan Mudiartha Utama ${ }^{2}$
}

\author{
${ }^{1,2}$ Fakultas Ekonomi dan Bisnis Universitas Udayana (Unud), Bali, Indonesia \\ E-mail: aguspraditya96@gmail.com
}

\begin{abstract}
ABSTRAK
Retensi karyawan merupakan upaya perusahaan untuk mempertahankan karyawan agar tetap di dalam perusahaan. Dalam mempertahankan karyawan perusahaan harus memperhatikan faktor-faktor yang mempengaruhi retensi karyawan. Tujuan penelitian ini adalah untuk menganalisis pengaruh budaya organisasi, komitmen organisasional, dan kompensasi terhadap retensi karyawan. Penelitian dilakukan di PT. Nindya Karya Wilayah IV Denpasar. Jumlah sampel sebanyak 37 orang karyawan, dengan penentuan sampel menggunakan metode purposive sampling (judgmental sampling). Pengumpulan data dilakukan melalui wawancara dan kuesioner. Teknik analisis data yang digunakan adalah regresi linear berganda. Hasil analisis menunjukkan bahwa budaya organisasi, komitmen organisasional, dan kompensasi berpengaruh positif dan signifikan terhadap retensi karyawan. Hal ini menunjukkan bahwa dengan budaya organisasi yang baik, komitmen organisasional yang tinggi, dan sistem kompensasi yang baik mendorong karyawan untuk tetap bertahan di dalam perusahaan. Untuk selanjutnya dalam upaya perusahaan mempertahankan karyawan yang memiliki kompetensi tinggi penting untuk memperhatikan ketiga variabel tersebut.
\end{abstract}

Kata kunci: budaya organisasi, komitmen organisasional, kompensasi, retensi karyawan

\begin{abstract}
Employee retention is the company's efforts to keep employees in the company. In retaining employees the company must pay attention to the factors that affect employee retention. The purpose of this study was to analyze the influence of organizational culture, organizational commitment, and compensation on employee retention. Research conducted at PT. Nindya Karya Region IV Denpasar. The number of samples is 37 employees, with the determination of the sample using the method of purposive sampling (judgmental sampling). Data collection was done through interviews and questionnaires. Data analysis technique used is multiple linear regression. The results of the analysis show that organizational culture, organizational commitment, and compensation have a positive and significant impact on employee retention. This shows that with a good organizational culture, high organizational commitment, and a good compensation system encourages employees to stay within the company. Furthermore, in the effort of the company to retain high competency employees it is important to pay attention to these three variables.
\end{abstract}

Keywords: organization culture, organizational commitment, compensation, employee retention 


\section{PENDAHULUAN}

Sumber daya manusia memiliki peranan dan tugas yang penting bagi sebuah perusahaan demi mewujudkan tujuan. Segala masalah yang terjadi dalam perusahaan memiliki dampak yang sangat besar terhadap bertahannya karyawan. Mathis dan Jackson (2006:126), menyatakan bahwa retensi merupakan upaya untuk mempertahankan karyawan agar tetap berada dalam organisasi guna mencapai tujuan organisasi tersebut. Demi mencapai tujuan sesuai dengan visi dan misi, perusahaan harus mampu mempertahankan karyawan dalam jangka waktu yang lama. Swambawa (2016), menyatakan bahwa mempertahankan karyawan merupakan tugas dan tanggung jawab perusahaan itu sendiri.

Pandangan seorang pengusaha, retensi karyawan adalah lamanya karyawan tinggal di perusahaan yang secara tidak langsung dapat disebut sebagai sikap karyawan terhadap perusahaan. Jennifer (2005:2) menyebutkan, retensi karyawan adalah suatu cara yang digunakan manajemen untuk mempertahankan karyawan yang kompeten agar tetap bertahan dalam perusahaan dalam jangka waktu tertentu. Oladopo (2014) menyebutkan, jika karyawan tidak dapat menggunakan potensinya dengan penuh dan juga tidak dihargai atau didengar di tempat mereka bekerja, maka mereka akan keluar karena stres dan frustrasi. Retensi karyawan merupakan kemampuan yang dimiliki perusahaan untuk mempertahankan karyawan yang memiliki potensi untuk tetap loyal terhadap perusahaan (Susilo, 2013).

Fenomena yang terjadi dalam perusahaan, khususnya perusahaan yang ada di Bali yaitu PT. Nindya Karya yang merupakan wilayah IV dari seluruh cabang 
I Putu Agus Praditya Adi Putra, Pengaruh Budaya Organisasi...

yang ada di Indonesia. PT. Nindya Karya merupakan salah satu perusahaan yang mampu mempertahankan karyawan dalam jangka waktu yang lama. PT. Nindya Karya merupakan perusahaan BUMN yang bergerak di bidang jasa kontruksi dan telah menjadi perusahaan besar yang saat ini beroperasi di seluruh wilayah Indonesia. PT. Nindya Karya memiliki karyawan sebanyak 640 orang di seluruh Indonesia, 337 orang merupakan lulusan S1 dan S2 Teknik serta Non Teknik, 104 orang Diploma Teknik dan Non Teknik. Dalam mencapai dan mewujudkan tujuan dari suatu perusahaan atau instansi, sebagaimana yang telah ditetapkan dalam visi dan misi-nya, PT. Nindya Karya menghadirkan sumber daya manusia terbaik yang mempunyai kemampuan dan ketrampilan khusus untuk memenuhi kualifikasi pekerjaan yang dibutuhkan.

Berdasarkan hasil wawancara dengan 5 orang karyawan tetap yang bekerja pada PT. Nindya Karya Wilayah IV mereka menyatakan bahwa niat untuk bertahan di dalam perusahaan sangat tinggi. Rata-rata karyawan meninggalkan perusahaan karena alasan akan menikah atau karena faktor umur, dan pekerjaan yang didapat tidak sesuai dengan kemampuan yang dimiliki. Lebih banyak karyawan yang tetap bertahan di dalam perusahaan karena budaya organisasi yang baik dan didukung dengan adanya aturan budaya organisasi yang dimiliki perusahaan.

Perusahaan memiliki budaya organisasi yang baik, karyawan yang bekerja juga memiliki komitmen organisasional yang tinggi untuk tetap bertahan di dalam perusahaan. Hal tersebut juga didorong oleh kompensasi yang diberikan kepada karyawan sangat baik sehingga karyawan mau bertahan untuk jangka waktu yang 
lama. Kompensasi yang diberikan selain gaji di atas UMR untuk mereka yang sudah bekerja selama 1 tahun, akan diberikan kompensasi kenaikan gaji setiap tahun. Selain gaji, bonus juga diberikan kepada karyawan yang menyelesaikan pekerjaan dengan baik. Perusahaan juga memberikan tunjangan kesehatan dan tunjangan fasilitas agar karyawan mampu bekerja dengan maksimal demi mencapai tujuan perusahaan.

Bertahannya karyawan di dalam perusahaan untuk jangka waktu yang panjang juga didukung dengan adanya budaya organisasi yang baik pada perusahaan PT. Nindya Karya Wilayah IV. Omotayo (2013), menyatakan bahwa budaya organisasi dapat menjadi sarana untuk menjaga agar karyawan tetap sejalan dan menyesuaikannya dengan tujuan organisasi. Joushan (2015), menyatakan bahwa semakin baik nilai budaya organisasi yang dianut, maka semakin tinggi juga tingkat kinerja karyawanya yang menandakan semakin baik kinerja karyawan maka semakin besar niat karyawan untuk bertahan dalam perusahaan untuk jangka waktu yang lama. (Chatterjee (2009), Mita (2014), Sheridan (1992), Mathis dan Jackson (2006: 128), dan Luthans (2006: 125)), juga membuktikan bahwa budaya organisasi berpengaruh positif dan signifikan terhadap retensi karyawan.

Karyawan mau bertahan di dalam perusahaan juga karena memiliki komitmen yang tinggi terhadap perusahaan. Linda (2013) menyatakan komitmen organisasional merupakan perspektif yang bersifat keperilakuan dimana komitmen diartikan sebagai perilaku yang konsisten dengan aktivitas (consistent lines of activity), sehingga semakin tinggi komitmen karyawan terhadap organisasi dapat 
I Putu Agus Praditya Adi Putra, Pengaruh Budaya Organisasi...

meningkatkan rasa ingin bertahan dari karyawan tersebut. Komitmen organisasional merupakan suatu keadaan di mana karyawan memihak organisasi tertentu serta tujuan-tujuan dan keinginannya untuk mempertahankan keanggotaan dalam organisasi tersebut (Robbins dan Judge, 2013). Khodaparast (2012), menyatakan bahwa komitmen organisasi adalah perilaku yang terbentuk sebagai hasil dari hubungan orang-orang dengan organisasi dan membawa mereka untuk menjadi anggota tetap organisasi. (Coetzee (2012), Mita (2014), Kaur (2012), Anis (2011), dan Nguyen (2014)), juga membuktikan bahwa komitmen organisasional berpengaruh secara positif dan signifikan terhadap retensi karyawan

Karyawan PT. Nindya Karya Wilayah IV memiliki keinginan bertahan yang tinggi juga dikarenakan mendapatkan kompensasi dari perusahaan, sehingga kompensasi tersebut mampu meningkatkan retensi karyawan. Astuti (2014), menyatakan bahwa semakin besar kompensasi maka akan semakin tinggi tingkat retensi karyawan. Feng (2016), menyatakan bahwa tidak mengherankan karyawan yang dibayar lebih banyak merasa puas dengan pekerjaan mereka dan kurang cenderung meninggalkan atasan mereka. (Masqsood et al. (2015), Mita (2014), Swambawa (2016), Kumar et al. (2012), Maqsood et al. (2015), dan Palwasha et al. (2016)), juga membuktikan bahwa kompensasi berpengaruh positif dan signifikan terhadap retensi karyawan.

Berdasarkan latar belakang, maka rumusan masalah penelitian adalah sebagai berikut: 1) Bagaimana pengaruh budaya organisasi terhadap retensi karyawan PT. Nindya Karya Wilayah IV? 2) Bagaimana pengaruh Komitmen 
organisasional terhadap retensi karyawan PT. Nindya Karya Wilayah IV? 3) Bagaimana pengaruh kompenasi terhadap retensi karyawan PT. Nindya Karya Wilayah IV?

Berdasarkan latar belakang dan rumusan masalah, maka tujuan dari penelitian ini adalah: 1) Untuk menjelaskan pengaruh budaya organisasi terhadap retensi karyawan PT. Nindya Karya Wilayah IV. 2) Untuk menjelaskan pengaruh komitmen organisasional terhadap retensi karyawan PT. Nindya Karya Wilayah IV. 3) Untuk menjelaskan pengaruh kompensasi terhadap retensi karyawan PT. Nindya Karya Wilayah IV. Berdasarkan rumusan masalah dan tujuan penelitian, berikut merupakan hipotesis penelitian yang dikutip dari hasil peneltian terdahulu.

Berbagai alasan yang dikutip mengenai keputusan karyawan untuk bertahan adalah budaya organisasi, dukungan dari rekan kerja dan atasan, peluang pertumbuhan, masalah yang berkaitan dengan kompensasi, kegiatan keterlibatan karyawan, pelatihan dan pengembangan, lingkungan kerja positif dan kondisi kerja yang baik (Mita, 2014). Sheridan (1992), mendapatkan hasil bahwa nilai budaya organisasi akan memiliki pengaruh signifikan terhadap tingkat retensi. Mathis dan Jackson (2006:128) menyatakan budaya merupakan hal yang penting dalam mempertahankan karyawan. Luthans (2006:125-126) menyatakan bahwa budaya merupakan hal yang penting dalam mempertahankan karyawan. Ada analisis terbaru dari perusahaan fortune yang menemukan bahwa atribut yang paling berhubungan dengan mereka yang menduduki peringkat tiga teratas dalam industri adalah "menarik dan mempertahankan orang-orang yang punya talenta mengagumkan". Cara yang dilakukan perusahaan tersebut adalah menanggapi 
I Putu Agus Praditya Adi Putra, Pengaruh Budaya Organisasi...

budaya dan nilai mereka secara serius. Chatterjee (2009), menerima kesimpulan bahwa budaya organisasi dan lingkungan kerja berperan penting dalam memastikan retensi karyawan dalam perusahaan.

$\mathrm{H}_{1}$ : Budaya organisasi berpengaruh positif dan signifikan terhadap retensi karyawan

Mita (2014), mandapatkan hasil bahwa komitmen karyawan memiliki peran penting dalam peningkatan retensi karyawan, ketidakhadiran yang rendah dan niat untuk pergi. Oleh karena itu komitmen karyawan dengan cara membantu retensi karyawan dan strategi retensi karyawan harus dijaga. Kaur (2012), menyatakan bahwa retensi karyawan benar-benar dipengaruhi oleh komitmen organisasional. Anis (2011), menyatakan bahwa komitmen organisasional memiliki hubungan yang positif dengan retensi karyawan. Coetzee (2012), mendapatkan hasil bahwa komitmen organisasional berpengaruh secara positif dan signifikan terhadap retensi karyawan. Nguyen (2014), menyatakan bahwa seluruh komponen (afektif, berkelanjutan, dan normatif) dari komitmen organisasional berhubungan positif dan signifikan dengan retensi karyawan.

$\mathrm{H}_{2}$ : Komitmen organisasional berpengaruh positif dan signifikan terhadap retensi karyawan

Mita (2014), mendapatkan hasil bahwa untuk mempertahankan organisasi yang lebih baik harus meningkatkan gaji / tunjangan serta faktor-faktor seperti kondisi kerja yang baik, timing kerja yang fleksibel, tim kooperatif, atasan, budaya dan nilai-nilai organisasi yang baik. Swambawa (2016), menyatakan bahwa kompensasi berpengaruh positif terhadap retensi karyawan. Kumar et al. (2012), menemukan bahwa karyawan akan merasa dihargai oleh perusahaan jika 
mereka mendapatkan kompensasi yang layak. Secara tidak langsung karyawan akan termotivasi serta memiliki niat untuk tinggal di perusahaan. Masqsood et al. (2015), menemukan bahwa kompensasi berkontribusi untuk meningkatkan retensi karyawan. Palwasha et al. (2016), menemukan bahwa kompensasi sebagai faktor penting yang mempengaruhi niat karyawan untuk tinggal.

$\mathrm{H}_{3}$ : Kompensasi berpengaruh positif dan signifikan terhadap retensi karyawan Berdasarkan hipotesis yang telah diuraikan sebelumnya, maka dapat digambarkan kerangka konseptual sebagai berikut:

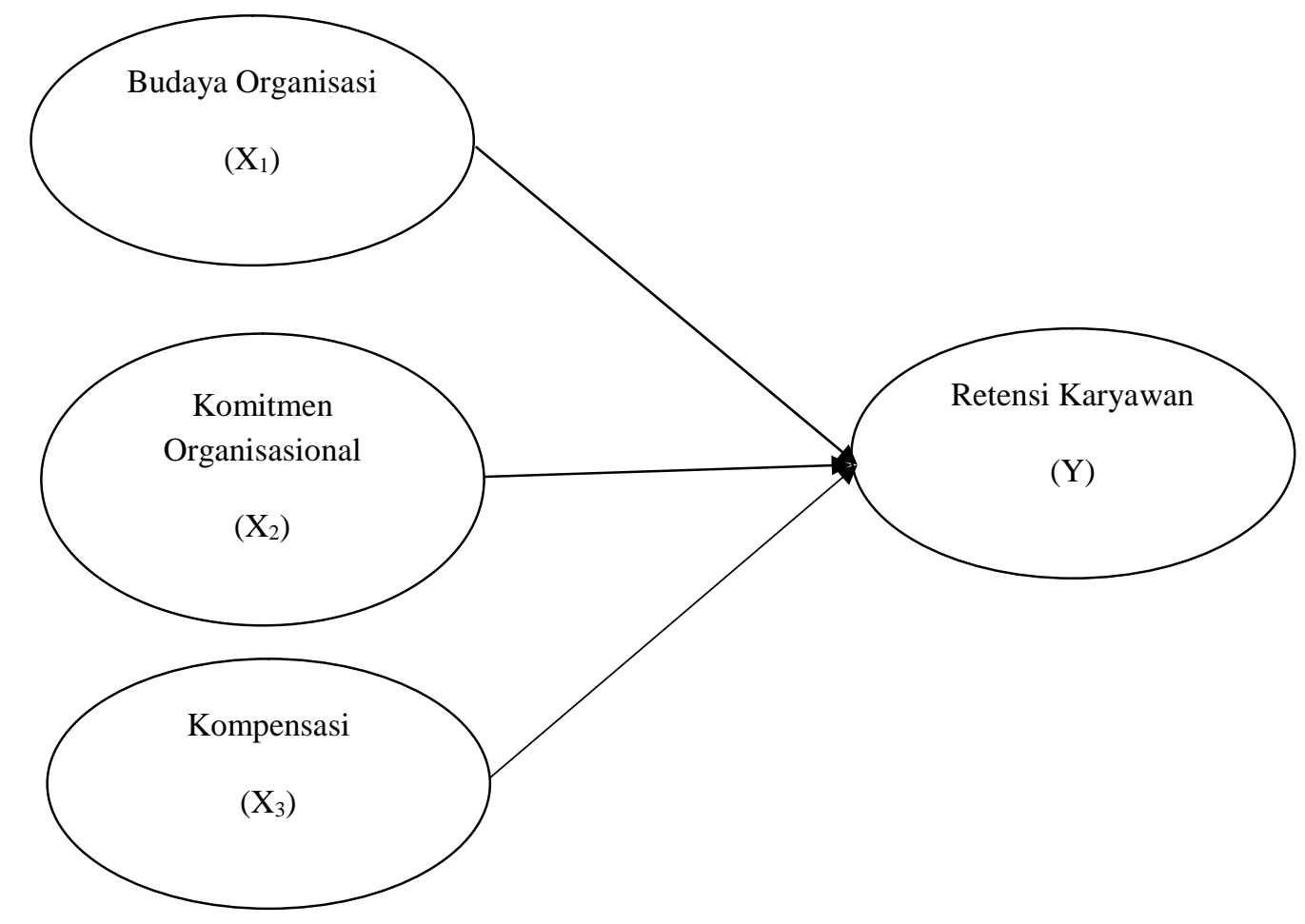

Gambar 1. Kerangka Konseptual

\section{METODE PENELITIAN}

Penelitian yang digunakan pada penelitian ini merupakan penelitian deskripsi/survey yaitu suatu metode dalam meneliti status sekelompok manusia, suatu sistem pemikiran atau suatu kelas peristiwa pada masa sekarang. Tujuannya 
I Putu Agus Praditya Adi Putra, Pengaruh Budaya Organisasi...

adalah membuat deskripsi, gambaran secara sistematis, faktual dan akurat mengenai fakta-fakta, sifat-sifat serta hubungan antar fenomena yang diselidiki (Rahyuda, 2016:27). Variabel yang diteliti yaitu variabel terikat retensi karyawan (Y) dan variabel bebasnya budaya organisasi $\left(\mathrm{X}_{1}\right)$, komitmen organisasional $\left(\mathrm{X}_{2}\right)$, dan kompensasi $\left(\mathrm{X}_{3}\right)$. Lokasi penelitian dilakukan pada perusahaan PT. Nindya Karya Wilayah IV Jalan Hayam Wuruk No. 149, Denpasar. Lokasi ini dipilih karena perusahaan memiliki tingkat retensi karyawan yang tinggi.

Pada Penelitian ini, jumlah populasi adalah 37 Karyawan tetap PT. Nindya Karya Wilayah IV. Metode penentuan sampel dilakukan dengan purposive sampling (judgmental sampling), yaitu teknik pengambilan sampel secara sengaja atau berdasarkan pertimbangan tertentu dalam memilih anggota populasi sebagai sampel, sesuai dengan kriteria yang disyaratkan dalam penelitian (Istijanto, 2006:117).

Penelitian ini menggunakan teknik analisis statstika inferensia dengan menggunakan metode regresi linier berganda. Teknik analisis ini digunakan untuk mengetahui pengaruh Budaya Organisasi $\left(\mathrm{X}_{1}\right)$, Komitmen Organisasional $\left(\mathrm{X}_{2}\right)$, Kompensasi $\left(\mathrm{X}_{3}\right)$ dan Retensi Karyawan (Y). Metode ini diuji menggunakan sistem komputer berupa spss.21. Pengaruh variabel independen terhadap variabel dependen diuji dengan tingkat kepercayaan 95\% atau $\alpha=5 \%$. Model regresi yang digunakan adalah sebagai berikut:

$$
Y=\alpha+\beta_{1} X_{1}+\beta_{2} X_{2}+\beta_{3} X_{3}+\varepsilon
$$

Keterangan:

$\mathrm{Y}=$ Retensi Karyawan

$\mathrm{X}_{1}=$ Budaya Organisasi 
$\mathrm{X}_{2}=$ Komitmen Organisasional

$\mathrm{X}_{3}=$ Kompensasi

$\alpha=$ Konstanta

$\beta_{1}=$ Koefisien regresi Budaya Organisasi

$\beta_{2}=$ Koefisien regresi Komitmen Organisasional

$\beta_{3}=$ Koefisien regresi Kompensasi

Uji asumsi klasik berfungsi untuk menilai persyaratan yang harus dipenuhi dalam teknik regresi linear berganda agar mendapatkan hasil yang valid. Uji asumsi klasik yang digunakan dalam penelitian ini adalah: 1) Uji normalitas, uji normalitas bertujuan untuk menguji apakah dalam residual dari model regresi yang dibuat apakah berdistribusi normal atau tidak (Suyana, 2016:102). Uji normalitas pada penelitian ini menggunakan uji Komogrovo-Smirnov data berdistribusi normal jika sig(2-tailed) lebih besar dari $0.05(\alpha=5 \%)$. 2) Uji heteroskedastisitas, uji heteroskedastisitas bertujuan menguji apakah dalam model regresi terjadi ketidaksamaan varians dari residual satu pengamatan ke pengamatan lainnya. Model regresi yang baik, tidak mengandung gejala heteroskedastisitas ataupun mempunyai varians yang homogen dan bila suatu model regresi mengandung gejala heteroskedastisitas akan memberikan hasil yang menyimpang. 3) Uji multikolinieritas, uji Multikolinieritas bertujuan untuk menguji apakah pada model regresi ditemukan adanya korelasi antar variabel bebas. Untuk mendeteksi ada atau tidaknya korelasi antar sesama variabel bebas dilihat dari nilai tolerance dan nilai inflation factor (VIF), dan bila nilai tolerance lebih dari $10 \%$ atau kurang dari 10\%, maka tidak ada multikolinieritas.

Uji F digunakan untuk menunjukkan kelayakan model regresi linear berganda sebagai alat analisis yang menguji pengaruh variabel bebas terhadap variabel terikat. Uji $\mathrm{F}$ dilakukan dengan melihat nilai signifikansi, jika nilai 
signifikansi anova $<\alpha=0.05$ maka model ini dikatakan layak atau variabel bebas mampu menjelaskan variabel terikat. Selain uji F, untuk melihat kelayakan model regresi linear berganda juga menggunakan koefisien determinasi ( $R$ Square). Koefisien determinasi pada intinya mengukur seberapa jauh kemampuan model dalam menerangkan variasi variabel terikat.

Uji t digunakan untuk menguji pengaruh dari variabel Budaya Organisasi, Komitmen Organisasional dan Kompensasi terhadap variabel Retensi Karyawan terikatnya secara parsial. Cara menguji secara parsial yaitu Jika nilai $t_{\text {tabel }}$ lebih besar dari nilai thitung dari $\beta_{1} / \beta_{2} / \beta_{3}$ atau tingkat signifikansi $\beta_{1} / \beta_{2} / \beta_{3}<\alpha 5 \%$ maka dapat dikatakan variabel Budaya Organisasi, Komitmen Organisasional, dan kompensasi berpengaruh terhadap Retensi Karyawan. Jika nilai $t_{\text {tabel }}$ lebih kecil dari nilai thitung $\beta_{1} / \beta_{2} / \beta_{3}$ atau tingkat signifikansi $\beta_{1} / \beta_{2} / \beta_{3}>\alpha$. $5 \%$ maka dapat dikatakan variabel Budaya Organisasi, Komitmen Organisasional, dan kompensasi tidak berpengaruh terhadap Retensi Karyawan. Kebenaran dari hipotesis itu harus dibuktikan melalui data yang terkumpul (Sugiyono, 2013:221).

\section{HASIL DAN PEMBAHASAN}

PT. Nindya Karya berkomitmen meningkatkan kinerja perusahaan melalui “NINDYA Reborn” yang berdasarkan pada PP No. 69 tahun 2012 dengan melakukan retrukturisasi perusahaan secara menyeluruh. PT. Nindya Karya berencana mengembangkan sistem struktur pracetak Nindya SpirCON sebagai suatu sistem struktur yang dapat diterapkan pada bangunan bertingkat menengah, dimana selain dapat diaplikasikan pada bangunan RUSUNAWA \& RUSUNAMI, dapat pula diaplikasikan pada bangunan lainnya, seperti bangunan apartemen, 
perkantoran, pertokoan, dan lainnya. Sebelum diterapkan, perlu dilakukan suatu penelitian dan pengembangan yang mempertimbangkan aspek teknis dan ekonomis serta lingkungan. PT. Nindya Karya memiliki karyawan sebanyak 640 orang di seluruh Indonesia, 337 orang merupakan lulusan S1 dan S2 Teknik serta Non Teknik, 104 orang Diploma Teknik dan Non Teknik. Dalam mencapai dan mewujudkan tujuan dari suatu perusahaan atau instansi, sebagaimana yang telah ditetapkan dalam visi dan misi-nya, PT. Nindya Karya menghadirkan sumber daya manusia terbaik yang mempunyai kemampuan dan ketrampilan khusus untuk memenuhi kualifikasi pekerjaan yang dibutuhkan.

Tabel 1.

Distribusi Responden Menurut Jenis Kelamin, Usia, dan Tingkat Pendidikan pada PT. Nindya Karya (Wilayah IV) Denpasar Tahun 2017

\begin{tabular}{cccc}
\hline No & Jenis Kelamin & Jumlah & \\
& & & Persen \\
1 & Laki-laki & 23 & 62,16 \\
2 & Perempuan & 14 & 37,83 \\
& Jumlah & $\mathbf{3 7}$ & $\mathbf{1 0 0}$ \\
No & Usia & Orang & Persen \\
& & 28 & 75,67 \\
2 & $21-23$ & 5 & 13,51 \\
3 & $31-40$ & 3 & 8,10 \\
4 & $41-50$ & 1 & 2,70 \\
& $51-60$ & $\mathbf{3 7}$ & $\mathbf{1 0 0}$ \\
No & Jumlah & & Jumlah \\
& Pendidikan & Orang & Persen \\
2 & SMA & 11 & 29,72 \\
3 & D3 & 2 & 5,40 \\
& S1 & 24 & 64,86 \\
\hline
\end{tabular}

Sumber: Data diolah, 2018 
I Putu Agus Praditya Adi Putra, Pengaruh Budaya Organisasi...

Kriteria jenis kelamin responden dapat digunakan sebagai acuan untuk mengetahui proporsi responden laki-laki dan perempuan. Berdasarkan Tabel 1 dapat diuraikan bahwa pembagian unit kerja berdasarkan jenis kelamin yaitu, karyawan yang bekerja pada perusahaan didominasi oleh karyawan berjenis kelamin laki-laki. Hal itu dikarenakan pekerjaan yang terdapat pada perusahaan banyak memerlukan tenaga kerja laki-laki daripada perempuan.

Kriteria usia responden dapat digunakan sebagai acuan untuk mengetahui usia responden pada penelitian ini. Berdasarkan Tabel 1 dapat diuraikan bahwa rata-rata usia karyawan yang bekerja pada perusahaan didominasi oleh karyawan yang berusia antara 21-23 tahun yaitu sebanyak 28 orang. Hal tersebut berarti perusahaan memiliki jumlah karyawan yang rata-rata berusia muda dan dapat bertahan didalam perusahaan untuk jangka waktu yang panjang.

Kriteria tingkat pendidikan dapat digunakan sebagai acuan untuk mengetahui pendidikan terakhir responden pada penelitian ini. Berdasarkan Tabel 1 dapat diuraikan bahwa rata-rata tingkat pendidikan tertinggi yang dimiliki perusahaan adalah pendidikan S1 yang berjumlah 24 orang. Hal tersebut berarti perusahaan memiliki standard kualitas karyawan yang baik karena memiliki lebih banyak karyawan yang bekerja dengan tingkat pendidikan S1 dalam perusahaan.

Hasil uji validitas instrumen penelitian disajikan pada Tabel 2 yang menunjukkan bahwa seluruh indikator dalam variabel budaya organisasi, komitmen organisasional, kompensasi, dan retensi karyawan memiliki nilai Pearson Correlation yang lebih besar dari angka 0,30 sehingga seluruh indikator 
tersebut dikatakan telah memenuhi syarat validitas data dan dapat dipakai untuk melakukan penelitian atau menguji hipotesis penelitian.

Tabel 2.

Hasil Uji Validitas

\begin{tabular}{llll}
\hline Variabel & Instrumen & Pearson Correlation & Keterangan \\
\hline \multirow{3}{*}{ Budaya Organisasi } & X1.1 & 0,775 & Valid \\
(X1) & X1.2 & 0,837 & Valid \\
& X1.3 & 0,901 & Valid \\
& X1.4 & 0,888 & Valid \\
& X1.5 & 0,900 & Valid \\
& X2.1 & 0,738 & Valid \\
& X2.2 & 0,817 & Valid \\
Komitmen Organisasional & X2.3 & 0,746 & Valid \\
(X2) & X2.5 & 0,895 & Valid \\
& X2.6 & 0,877 & Valid \\
& X2.7 & 0,757 & Valid \\
& X2.8 & 0,890 & Valid \\
& X3.1 & 0,751 & Valid \\
& X3.2 & 0,760 & Valid \\
Kompensasi & X3.3 & 0,695 & Valid \\
(X3) & X3.4 & 0,788 & Valid \\
& X3.5 & 0,864 & Valid \\
Retensi Karyawan & X3.6 & 0,858 & Valid \\
(Y) & X3.7 & 0,798 & Valid \\
& Y.1 & 0,936 & Valid \\
\hline
\end{tabular}

Sumber: Dara diolah, 2018

Tabel 3.

Hasil Uji Reliabilitas

\begin{tabular}{llll} 
No. & Variabel & Cronbach's Alpha & Keterangan \\
\hline 1. & Budaya Organisasi & 0,912 & Reliabel \\
2. & Komitmen Organisasional & 0,931 & Reliabel \\
3. & Kompensasi & 0,898 & Reliabel \\
4. & Retensi Karyawan & 0,839 & Reliabel \\
\hline \multicolumn{2}{l}{ Sumber: Data diolah, 2018 } &
\end{tabular}

Hasil uji reliabilitas instrumen pada penelitian ini disajikan pada Tabel 3 yang menunjukkan bahwa keempat instrumen penelitian ini yaitu budaya organisasi, komitmen organisasional, kompensasi, dan retensi karyawan memiliki 
koefisien cronbach's alpha yang lebih besar dari angka 0,60 sehingga pernyataan pada kuesioner dapat dikatakan reliabel.

Tabel 4.

Hasil Analisis Regresi Linear Berganda

\begin{tabular}{|c|c|c|c|c|c|}
\hline \multirow[t]{2}{*}{ Model } & \multicolumn{2}{|c|}{$\begin{array}{l}\text { Unstandardized } \\
\text { Coefficients }\end{array}$} & \multirow{2}{*}{$\begin{array}{l}\text { Standardized } \\
\text { Coefficients } \\
\text { Beta }\end{array}$} & \multirow[t]{2}{*}{$\mathbf{t}$} & \multirow[t]{2}{*}{ Sig. } \\
\hline & B & Std. Error & & & \\
\hline (Constant) & 3,932 & 1,224 & & 1,840 & 0,084 \\
\hline Budaya Organisasi & 0,449 & 0,149 & 0,308 & 3,774 & 0,009 \\
\hline Komitmen & 0,496 & 0,103 & 0,383 & 2,472 & 0,002 \\
\hline Organisasional & 0,292 & 0,073 & 0,342 & 2,606 & 0,011 \\
\hline \multicolumn{6}{|l|}{ Kompensasi } \\
\hline $\mathrm{R}$ & 0,783 & & & & \\
\hline $\mathrm{R}^{2}$ & 0,613 & & & & \\
\hline Adjusted $\mathrm{R}^{2}$ & 0,584 & & & & \\
\hline F hitung & 23,052 & & & & \\
\hline Sig. F & 0,000 & & & & \\
\hline
\end{tabular}

Sumber: Data diolah, 2018

Interpretasi dari persamaan regresi diatas adalah sebagai berikut: $\mathrm{X}_{1}=$ 0,449. Nilai tersebut menunjukan bahwa budaya organisasi berpengaruh positif terhadap retensi karyawan pada karyawan tetap PT. Nindya Karya Wilayah IV sebesar 0,449 yang artinya apabila budaya organisasi meningkat, maka retensi karyawan juga akan meningkat.

$\mathrm{X}_{2}=0,496$. Nilai tersebut menunjukan bahwa komitmen organisasional berpengaruh positif terhadap retensi karyawan pada karyawan tetap PT. Nindya Karya Wilayah IV sebesar 0,496 yang artinya apabila komitmen organisasional meningkat, maka retensi karyawan juga akan meningkat.

$\mathrm{X}_{3}=0,292$. Nilai tersebut menunjukan bahwa kompensasi berpengaruh positif terhadap retensi karyawan pada karyawan tetap PT. Nindya Karya Wilayah IV sebesar 0,292 yang artinya apabila kompensasi meningkat, maka retensi karyawan juga akan meningkat. 
Berdasarkan hasil uji pada Tabel 4 yaitu tabel hasil analisis regresi liner berganda untuk menguji apakah data yang digunakan normal atau tidak, dapat dilakukan dengan menggunakan uji Kolmogorov-Smirnov dengan melihat nilai Asymp. Sig. (2-tailed). Jika nilai Asymp. Sig. (2-tailed) lebih besar taraf signifikansi yang ditetapkan yaitu 5 persen $(0,05)$, maka data telah berdistribusi normal. Berdasarkan hasil analisis, diperoleh hasil sebesar 0,904 > 0, 05 yang artinya data berdistribusi normal.

Berdasarkan hasil olah data, maka hasil uji heteroskedastisitas pada penelitian ini disajikan pada Tabel 5.

\section{Tabel 5.} Hasil Uji Heteroskedastisitas

\begin{tabular}{lll}
\hline Model & Sig. & Keterangan \\
\hline Budaya Organisasi & 0,507 & Lolos Uji \\
Komitmen Organisasional & 0,285 & Lolos Uji \\
Kompensasi & 0,300 & Lolos Uji \\
Sumber: Data diolah, 2018 & &
\end{tabular}

Untuk mengetahui ada atau tidaknya heteroskedastisitas yaitu dengan melakukan Uji Glejser dengan meregresi nilai absolut terhadap variabel independen, dengan ketentuan jika nilai signifikan di atas 0, 05 maka memiliki arti tidak terjadi heteroskedastisitas. Hasil uji menunjukkan nilai signifikansi lebih dari 0, 05 yang artinya model regresi bebas dari gejala heteroskedastisitas.

Berdasarkan hasil olah data, maka hasil uji multikolinieritas pada penelitian ini disajikan pada Tabel 6. 
Tabel 6.

\begin{tabular}{|c|c|c|}
\hline \multicolumn{3}{|c|}{ Hasil Uji Multikolinearitas } \\
\hline Model & $\begin{array}{l}\text { Colinearit } \\
\text { Tolerance }\end{array}$ & $\begin{array}{l}\text { Statistic } \\
\text { VIF }\end{array}$ \\
\hline Budaya Organisasi & 0,259 & 3,864 \\
\hline Komitmen Organisasional & 0,323 & 3,097 \\
\hline Kompensasi & 0,378 & 2,643 \\
\hline
\end{tabular}

Untuk mendeteksi ada atau tidaknya multikolinearitas dalam model regresi yaitu mempunyai angka Tolerance $>0,10$ atau mempunyai nilai VIF $<10$. Berdasarkan hasil analisis, dapat dilihat bahwa koefisien Tolerance semua variabel lebih besar dari 0, 10 dan nilai VIF yang lebih kecil dari 10 . Hasil ini mengindikasikan bahwa tidak terdapat gejala multikolinear dari model regresi yang dibuat sehingga pada model regresi ditemukan korelasi antar variabel bebas.

Berdasarkan hasil uji pada Tabel 4 yaitu tabel hasil analisis regresi liner berganda, nilai signifikansi $\mathrm{F}$ adalah sebesar 0,000 yang lebih kecil dari 0, 05 ( $\mathrm{F}<$ $\alpha$ ) yang berarti variabel bebas yaitu budaya organisasi $\left(\mathrm{X}_{1}\right)$, komitmen organisasional $\left(\mathrm{X}_{2}\right)$, dan kompensasi $\left(\mathrm{X}_{3}\right)$ berpengaruh signifikan secara serempak atau bersama-sama terhadap variabel terikat yaitu retensi karyawan (Y), sehingga penelitian ini dapat dikatakan memenuhi uji kelayakan model atau model penelitian dinyatakan layak digunakan sebagai model regresi.

Berdasarkan hasil uji pada Tabel 4 yaitu tabel hasil analisis regresi liner berganda, hasil koefisien determinasi besarnya nilai $\mathrm{R}^{2}$ adalah sebesar 0,584 yang artinya sebesar 58,4 persen variasi retensi karyawan dipengaruhi oleh budaya organisasi, komitmen organisasional, dan kompensasi, sedangkan sisanya sebesar 41,6 persen dipengaruhi oleh faktor-faktor lain yang tidak dimasukkan ke dalam model penelitian. 
Hasil penelitian menunjukkan bahwa budaya organisasi pada perusahaan PT. Nindya Karya Wilayah IV baik, karena karyawan perusahaan PT. Nindya Karya Wilayah IV telah mampu memperhatikan dengan jeli setiap permasalahan yang mungkin menimbulkan kerugian bagi organisasi, karyawan juga mampu memberi perhatian pada permasalahan secara detail, karyawan selalu berorientasi terhadap hasil yang akan dicapai. Karyawan selalu berorientasi kepada semua kepentingan anggota, dan karyawan juga selalu agresif dalam bekerja.

Hasil penelitian juga menunjukkan adanya hubungan antara budaya organisasi dengan retensi karyawan. Hal ini sejalan dengan hasil penelitian yang dilakukan Mita (2014) mendapatkan hasil penelitian yaitu berbagai alasan yang dikutip mengenai keputusan karyawan untuk bertahan adalah budaya organisasi, dukungan dari rekan kerja dan atasan, peluang pertumbuhan, masalah yang berkaitan dengan kompensasi, kegiatan keterlibatan karyawan, pelatihan dan pengembangan, lingkungan kerja positif dan kondisi kerja yang baik. Sheridan (1992), mendapatkan hasil bahwa nilai budaya organisasi akan memiliki pengaruh signifikan terhadap tingkat retensi. Mathis dan Jackson (2006:128) menyatakan budaya merupakan hal yang penting dalam mempertahankan karyawan.

Luthans (2006:125-126) menyatakan bahwa budaya merupakan hal yang penting dalam mempertahankan karyawan. Ada analisis terbaru dari perusahaan fortune yang menemukan bahwa atribut yang paling berhubungan dengan mereka yang menduduki peringkat tiga teratas dalam industri adalah "menarik dan mempertahankan orang-orang yang punya talenta mengagumkan”. Cara yang dilakukan perusahaan tersebut adalah menanggapi budaya dan nilai mereka secara 
serius. Chatterjee (2009), menerima kesimpulan bahwa budaya organisasi dan lingkungan kerja berperan penting dalam memastikan retensi karyawan dalam perusahaan.

Hasil penelitian menunjukkan bahwa komitmen organisasional pada perusahaan PT. Nindya Karya Wilayah IV tinggi, karena karyawan telah merasa terikat secara emosional terhadap perusahaan, karyawan telah merasa menjadi bagian keluarga dari perusahaan, karyawan telah merasa ikut memiliki perusahaan, karyawan merasa kehidupannya akan terganggu dan mendapatkan konsekuensi yang tidak dapat ditanggung karyawan jika meninggalkan perusahaan, karyawan akan tetap tinggal dalam perusahaan karena komitmen karyawan terhadap perusahaan, dan karyawan telah merasa loyal dan setia terhadap perusahaan. Berdasarkan hasil analisis dari ketiga variabel yang telah diuji, variabel komitmen organisasional merupakan variabel yang sangat mempengaruhi retensi karyawan.

Hasil penelitian juga menunjukkan adanya hubungan antara komitmen organisasional dengan retensi karyawan. Hal ini sejalan dengan hasil penelitian yang dilakukan Mita (2014), mendapatkan bahwa komitmen karyawan dapat memiliki peran penting dalam peningkatan retensi karyawan, ketidakhadiran yang rendah dan niat untuk pergi. Oleh karena itu komitmen karyawan dengan cara membantu retensi karyawan dan strategi retensi karyawan harus dijaga. Kaur (2012), menyatakan bahwa retensi karyawan benar-benar dipengaruhi oleh komitmen organisasional. 
Anis (2011), menyatakan bahwa komitmen organisasional memiliki hubungan yang positif dengan retensi karyawan. Coetzee (2012), mendapatkan hasil bahwa Komitmen Organisasional berpengaruh secara positif dan signifikan terhadap retensi karyawan. Nguyen (2014), menunjukan bahwa seluruh komponen (afektif, berkelanjutan, dan normatif) dari komitmen organisasional berhubungan positif dan signifikan dengan retensi karyawan.

Hasil penelitian menunjukkan bahwa kompensasi pada perusahaan PT. Nindya Karya Wilayah IV baik, karena karyawan perusahaan PT. Nindya Karya Wilayah IV telah mendapatkan gaji tepat waktu setiap bulannya, karyawan mendapatkan bonus jika mampu memenuhi target perusahaan. Karyawan telah mendapatkan tunjangan hari raya setiap tahun, tunjangan bayaran cuti tahunan, dan tunjangan berupa dana pensiun. Karyawan juga mendapatkan fasilitas kesehatan, fasilitas keluarga, dan fasilitas untuk bekerja.

Hasil penelitian juga menunjukkan adanya hubungan antara kompensasi dengan retensi karyawan. Hal ini sejalan dengan hasil penelitian yang dilakukan Menurut Mita (2014), mendapatkan hasil bahwa untuk mempertahankan organisasi yang lebih baik harus meningkatkan gaji / tunjangan serta faktor-faktor seperti kondisi kerja yang baik, timing kerja yang fleksibel, tim kooperatif, atasan, budaya dan nilai-nilai organisasi yang baik. Swambawa (2016), menyatakan bahwa kompensasi berpengaruh positif terhadap retensi karyawan. Kumar et al. (2012), menemukan bahwa karyawan akan merasa dihargai oleh perusahaan jika mereka mendapatkan kompensasi yang layak. Secara tidak langsung karyawan akan termotivasi serta memiliki niat untuk tinggal di perusahaan. Masqsood et al. 
I Putu Agus Praditya Adi Putra, Pengaruh Budaya Organisasi...

(2015), menemukan bahwa kompensasi berkontribusi untuk meningkatkan retensi karyawan. Palwasha et al. (2016), menemukan bahwa kompensasi sebagai faktor penting yang mempengaruhi niat karyawan untuk tinggal.

Implikasi penelitian ini adalah menekankan pada manfaat nyata dari hasil penelitian untuk mampu mempertahankan karyawan dalam jangka waktu yang panjang dalam sebuah perusahaan khususnya PT. Nindya Karya Wilayah IV. Beberapa implikasi dari hasil penelitian yang sudah dilakukan diantaranya adalah pertama, terbukti bahwa responden merasa nyaman dan aman dengan budaya organisasi yang dimiliki oleh perusahaan sehingga responden mampu bertahan dalam perusahaan untuk jangka waktu yang lama.

Kedua, terbukti bahwa responden merasakan adanya komitmen yang tinggi antara karyawan dengan perusahaan. Hal ini menimbulkan adanya tingkat retensi karyawan yang tinggi dalam perusahaan. Bertahannya karyawan dalam perusahaan untuk jangka waktu yang lama juga membantu perusahaan untuk mencapai tujuan organisasi tersebut.

Ketiga, melalui penelitian ini juga terbukti bahwa responden bertahan dalam perusahaan dikarenakan perusahaan mampu memberikan kompensasi seperti gaji, fasilitas, dan tunjangan lainnya yang sebanding dengan beban kerja yang diberikan kepada karyawan. Sistem kompensasi yang baik dimiliki oleh perusahaan mampu membuat karyawan bertahan dalam perusahan untuk jangka waktu lama.

Sampel yang digunakan dalam penelitian ini tidak merupakan seluruh karyawan PT. Nindya Karya WIilayah IV yang terdiri dari karyawan tetap dan 
tidak tetap, sehingga menyebabkan hasil penelitian tidak dapat digeneralisasi untuk seluruh karyawan PT. Nindya Karya Wilayah IV.

Penelitian ini hanya dilakukan pada perusahaan PT. Nindya Karya Wilayah IV, sehingga menyebabkan cakupan penelitian masih kecil dan belum dapat sepenuhnya mewakili calon responden lain yang lebih berpotensi.

\section{SIMPULAN DAN SARAN}

Berdasarkan pembahasan yang telah diuraikan pada bab sebelumnya, maka diperoleh simpulan sebagai berikut: Budaya organisasi memiliki pengaruh positif dan signifikan terhadap retensi karyawan. Hal ini menunjukan bahwa ketika budaya organisasi diterapkan dengan baik di dalam perusahaan maka akan meningkatkan retensi karyawan. Komitmen Organisasional memiliki pengaruh positif dan signifikan terhadap retensi karyawan. Semakin tinggi komitmen organisasional yang dimiliki karyawan terhadap perusahaan maka akan meningkatkan retensi karyawan. Kompensasi memiliki pengaruh positif dan siginifikan terhadap retensi karyawan. Hal ini menunjukan bahwa semakin besar kompensasi yang diberikan perusahaan kepada karyawan maka akan meningkatkan retensi karyawan.

Saran yang dapat diberikan berdasarkan hasil penelitian dan pembahasan adalah sebagai berikut: Perusahaan harus mempertahankan budaya organisasi yang baik dengan menciptakan karyawan yang mampu bekerja dengan agresifitas yang tinggi. Perusahaan harus meningkatkan komiten organisasional yang tinggi dengan membuat karyawan merasa memiliki sedikit pilihan jika meninggalkan perusahaan. Perusahaan harus mampu memberikan tunjangan bayaran cuti 
tahunan yang merata bagi seluruh karyawan, mampu menciptakan peluang karir yang sama bagi setiap karyawan, maka karyawan akan mau bertahan di dalam perusahaan untuk jangka waktu yang lama.

\section{REFRENSI}

Abdul, Rashid. 2016. The influence of organizational culture on attitudes toward organizational change. Journal of Emerald Insight. 25 (2). pp 161-179.

Anis, Atif, Kashif-ur-Rehman, Ijaz-Ur-Rehman, Muhammad Asif Khan dan Asad Afzal Humayoun. 2011. Impact of organizational commitment on job satisfaction and employee retention in pharmaceutical industry. African Journal of Business Management. 5 (17). pp 7316-7324.

Astuti, Diah Puji. 2014. Pengaruh Kompensasi Terhadap Retensi Karyawan Melalui Kepuasan Kerja dan Komitmen Afektif Pada Beberapa Rumah Sakit di Jakarta. Jurnal Manajemen dan Pemasaran Jasa. 7 (1). hal. 199-217.

Chatterjee, Nandita. 2009. A Study of Organizational Culture and its effect on Employee Retention. Journal of Management; Bhubaneswar. 2 (2). pp 147-154.

Coetzee, A., and Imenda. 2012. Alternative Conceptions Held by First Year Physics Students at A South African University of Technology Concerning Interference and Diffraction of Waves. Research in Higher Educational Journal. 1 (6). pp 1-13.

Feng, Mingming. 2016. Monetary compensation, workforce-oriented corporate social responsibility, and firm performance. Journal of Emerald Insight. 30 (3). pp 196-215.

Istijanto. 2006. Riset Sumber Daya Manusia: Cara Praktis Mendeteksi DimensiDimensi Kerja Karyawan. Cetakan Kedua. Jakarta: PT Gramedia Pustaka Utama.

Jennifer A, Carsen. 2005. HR How to Employee Retention. Chicago: J.D. CCH Incorporated.

Joushan, Shindie Aulia, Muhammad Syamsun, Lindawati Kartika. 2015. Pengaruh Budaya Organisasi dan Employee Engagment Terhadap Kinerja 
Karyawan Pada PT. PLN (Persero) Area Bekasi. Jurnal Aplikasi Manajemen. 13 (4). hal. 697-703.

Kaur, Mahal. 2012. HR Practices as Determinants of Organizational Commitment and Employee Retention. The IUP Journal of Management Research. 6 (4). pp 38-53.

Khodaparast, Sareshkeh Siavash, Fatemeh Ghorbanalizadeh Ghaziani, Seyed Morteza Tayebi. 2012. Impact of Organizational Justice Perceptions on Job Satisfaction and Organizational Commitment: The Iranian Sport Federations Perspective. Annals of Biological Research. 3 (8). pp 4229-4238.

Kumar, Rames, Charles Ramendran dan Peter Jacob. 2012. An Effectiveness of Human Resource Management Practices on Employee Retention in Institute of Higher learning: - A Regression Analysis. International Journal of Business Research and Management. 3 (2). pp 60-79.

Luthans, Fred. 2006. Perilaku Organisasi. Edisi Sepuluh. Alih bahasa: Vivin Andhika Yuwono, Shekar Purwanti, Th. Arie Prabawati \& Winong Rosari. Yogyakarta: Penerbit Andi.

Masqsood, Haider, Rasli, Amran., Akhtar, Chaudhry Shoaib., Yusoff, Rosman Bin Mohammesd., Malik, Mujahid Malik., Aamir, Alamxeb., Arif, Ahmed., Naveed, Shaheryar.,and Tariq, Fariha. 2015. The Impact of Human Resource Practices on Employee Retention in the Telecom Sector. International Journal of Economics and Financial Issues, 5 (1). pp 63-69.

Mathis, Robert L dan Jackson, John H. 2006. Human Resumber Management. Tenthedition, Jakarta: Salemba empat.

Mita, Mehta, Aarti Kubertti, Ravneeta Dhankhar. 2014. Review Paper - Study on Employee Retention and Commitment. International Journal of Advance Research in Computer Science and Management Studies. 2 (2). pp 154-164.

Nguyen, Anh Kim, P Do, a Grall. 2014. Condition-Based Maintenance For MultiComponent Systems Using Importance Measure and Predictive Information. International Journal of Systems Science: Operations \& Logistic. 1 (4). pp 228-245. 
Oladopo, Victor. 2014. The Impact of Talent Management on Retention. Journal of Business Studies Quarterly. 5 (3). pp 20-36.

Omotayo, Adewale O, Adeniji Adenike A. 2013. Impact of Organizational Culture on Human Resource Practices: A Study of Selected Nigerian Private Universities. Journal of Competitiveness. 5 (4). pp 115-133.

Palwasha, Bibi., Ashfaq, Ahmad., and Abdul, HA Majid. 2016. The Moderating Role of Work Environment on the Relationship between Compensation, Job Security, and Employee Retention. International Journal of Economic Perspective; Famagusta. 10 (4). pp 726-738.

Rahyuda, Ketut. 2016. Metode Penelitian Bisnis. Udayana University Press.

Robbins, Stephen P dan Timothy A. Judge.2013. Organization Behavior Edisi 15. New Jersey: Pearson Education.

Sheridan, John E. 1992. Organizational Culture and Employee Retention. Academy Of Management Journal. 35 (5). pp 1036-1056.

Sugiyono. 2013. Metode Penelitian Pendidikan (Pendekatan Kualitatif, Kuantitatif, dan R\&D). Bandung: Alfabeta.

Suyana Utama, Made. 2016. Aplikasi Analisis Kuantitatif. CV. Sastra Utama: Denpasar.

Swambawa Putra, Ida Bagus Gede. 2016. Pengaruh Kompensasi, Lingkungan Kerja dan Perceived Organizational Support (POS) Terhadap Retensi Karyawan: Studi Kasus Pada Green Villas Hotel Tuban Bali. E-Jurnal Manajemen Unud. 5 (2). hal. 810-837. 